\title{
Role for Peptidylarginine Deiminase Enzymes in Disease and Female Reproduction
}

\author{
Sachi HORIBATA ${ }^{1)}$, Scott A. COONROD ${ }^{1)}$ and Brian D. CHERRINGTON ${ }^{2)}$ \\ 1) Baker Institute for Animal Health, College of Veterinary Medicine, Cornell University, NY 14853, USA \\ 2) Department of Zoology and Physiology, University of Wyoming, WY 82071, USA
}

\begin{abstract}
The peptidylarginine deiminases (PADs) are a family of calcium-dependent enzymes that post-translationally convert positively charged arginine residues to neutrally charged citrulline in a process called citrullination. There are five PAD family members (PAD1-4 and 6), each with unique tissue distribution patterns and functional roles including: cellular differentiation, nerve growth, apoptosis, inflammation, gene regulation, and early embryonic development. Previous review articles have focused on the expression and function of PADs and on their catalytic activity, citrullination, while other, more recent reviews have addressed the role of these enzymes in disease [1-3]. What has not been previously reviewed in any level of detail is the role that PAD proteins play in female reproduction. Given that: (1) PAD family members are highly represented in female reproductive tissues, (2) that some of the earlier PAD literature suggests that PADs play a critical role in female reproduction, and (3) that our studies have demonstrated that oocyte and early embryo restricted PAD6 is essential for female reproduction, we felt that a more comprehensive review of this topic was warranted.
\end{abstract}

Key words: Citrullination, Peptidylarginine deiminases (PADs), Reproduction

(J. Reprod. Dev. 58: 274-282, 2012)

$\mathbf{T}$ he peptidylarginine deiminases (PADs, PADIs or protein-Larginine iminohydrolase [EC 3.5.3.15]) are a family of calciumdependent enzymes that post-translationally convert positively charged arginine residues on target proteins to neutrally charged citrulline [3]. This activity is termed citrullination or deimination (Fig. 1) and the modification results in the disruption of ionic and hydrogen bonds within the substrate proteins causing wide-ranging effects on target protein structure, function, and protein-protein interactions $[1,4]$ (Fig. 2). The PAD gene family consists of five members (PAD1-4 and PAD6) located within a highly organized gene cluster on human chromosome $1 \mathrm{p} 36.13$ and on the orthologous region of mouse chromosome $4[3,5]$. PAD2 is believed to be the ancestral homologue, while the other PADs appear to have been derived from PAD2 via a series of gene duplications [3]. Each PAD enzyme has a unique tissue distribution pattern and substrate preferences which likely confers biological specificity.

\section{Expression and Function of PAD Family Members in Non-reproductive Tissues}

PAD1 is expressed from the basal to granular layer of the epidermis and a major function of this PAD in keratinocytes is to promote differentiation by citrullinating the intermediate filaments, keratin (including $\mathrm{K} 1$ and $\mathrm{K} 10)$ and filaggrin [3, 6]. The loss of charge following citrullination is believed to lead to disassembly of the

Received: December 7, 2011

Accepted: January 29, 2012

(C)2012 by the Society for Reproduction and Development

Correspondence: BC Cherrington (e-mail: bcherrin@uwyo.edu) and SA

Coonrod (e-mail: sac269@cornell.edu)

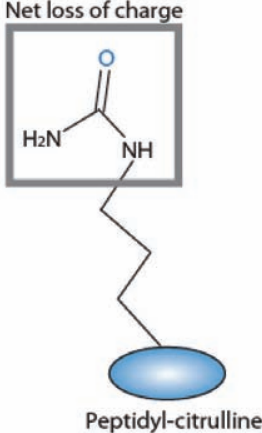

Fig. 1. Peptidylarginine deiminase (PAD) enzymes convert protein arginine residues to citrulline in a process called citrullination.

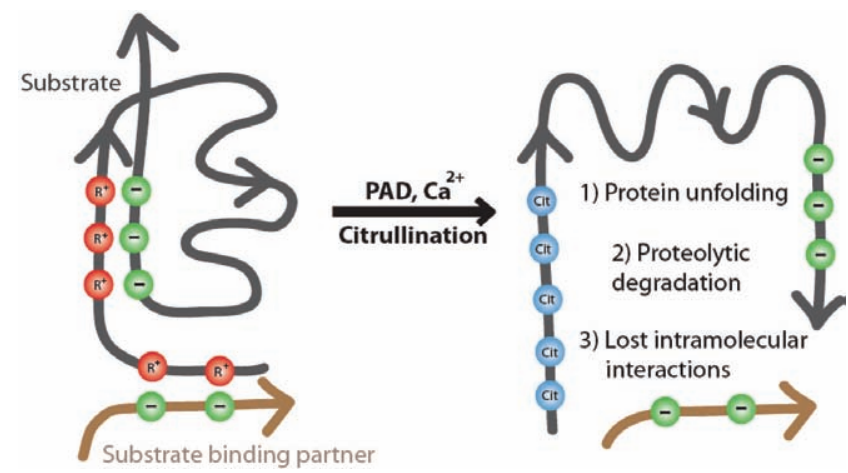

Fig. 2. The effects of PAD-catalyzed citrullination. 
cytokeratin-filaggrin complex and proteolytic degradation, thereby generating an amino acid pool that is required for maintenance of stratum corneum's barrier function [7-9]. Additionally, citrullination also reduces the flexibility of the keratin cytoskeleton due, in part, to cross-linking of keratin and filaggrin filaments, thus forming a rigid matrix that facilitates epidermal cornification [10-12].

PAD2 is the most widely expressed isoform and is present in a range of tissues including the brain, spinal cord, oligodendrocytes, skeletal muscle, pancreas, salivary gland, sweat gland, spleen, macrophage, bone marrow, and yolk sac [3, 13, 14]. While citrullination appears to be sparse in normal nervous tissue, a major substrate for PAD2 during the onset of neurodegenerative disease is myelin basic protein (MBP), a constituent of the myelin sheath. PAD2 is highly expressed in skeletal muscle, yet a role for this PAD in muscle function has not been described and levels of citrullinated proteins in skeletal muscle tissue actually appear to be very low [15]. In macrophages, PAD2 can citrullinate vimentin, a type 3 intermediate filament, resulting in filament network breakdown [16] and, eventually, apoptosis. Recently, PAD2 was linked to cytokine signaling during the immune response where it citrullinates IKK $\gamma$ in macrophages, causing suppression of NF-kB activity [17]. Additionally, PAD2 mediated citrullination of CXCL8 was also associated with suppression of the inflammatory response [18]. Regarding PAD2's subcellular localization, PAD2 has been previously characterized as localizing to the cytoplasm. However, newer evidence suggests that, in mammary epithelium and neural tissue at least, PAD2 is also found in the nucleus $[19,20]$. Our finding that PAD2 appears to target histones for citrullination suggests that, similar to PAD4, PAD2 may also play a role in gene regulation.

PAD3 expression seems to be limited to hair follicles and the epidermis [21]. In follicles, PAD3 has been found to citrullinate the structural protein, trichohyalin, in the inner root sheath cells causing conformational changes during hair growth [22]. It is believed that this activity results in a more soluble form of trichohyalin, thus facilitating trichohyalin's association with cytokeratins and cross-linking by transglutaminase to allow for directional hair growth $[4,23,24]$. Along with filaggrin, PAD3 is also expressed in keratinocytes of the highly differentiated epidermal granular layer where citrullination of filaggrin enhances its association with keratin to form a fibrous matrix that is required for cornification. Dysregulated citrullination of filaggrin by PAD3 in the epidermis is implicated with impaired epidermal homeostasis and loss of barrier function [25].

PAD4 is best characterized in cells of the hematopoietic lineage including monocytes, T cells, B cells, neutrophils, eosinophils, natural killer (NK) cells, and granulocytes [26, 27]. Newer reports, however, indicate that PAD4 is also expressed in mammary epithelial cells $[28,29]$. PAD4 is the only family member which possesses a canonical nuclear localization signal, and, in the nucleus, PAD4 has been found to citrullinate a range of factors involved in transcriptional regulation including; histone proteins, transcription factors, and transcription co-factors [28-31]. PAD4 was also recently found to regulate apoptosis and the cell cycle by regulating the expression of the p53 target genes p21, OKL38, CIP1 and WAF1; thus linking PAD4 activity with cancer [32, 33]. Additionally, PAD4 has also been found to mediate chromatin decondensation in HL-60 granulocytes and neutrophils via histone hypercitrullination [34].

PAD6 expression is limited to oocytes and early embryos and will be discussed in the Reproduction section below.

\section{PADs and Disease}

Recently, dysregulation of PADs has been associated with multiple disease states including rheumatoid arthritis, multiple sclerosis, Alzheimer's disease, and, increasingly, cancer. A discussion of the links between PADs and disease follows.

\section{Rheumatoid arthritis (RA)}

Among the PAD family members, PAD4 is perhaps the best characterized due to its close association with rheumatoid arthritis (RA). PAD4-mediated citrullination of fibrin and fibrinogen is frequently elevated in the synovial tissues of patients with RA $[35,36]$ and autoantibodies generated against citrullinated proteins are present in sera from patients with RA [37]. Additionally, antifilaggrin autoantibody (AFA) titer is closely correlated with RA severity and is, therefore, frequently used as serological markers to detect RA [38, 39]. Aside from AFAs, other known autoantibodies against citrullinated proteins include antiperinuclear factor (APF) and anti-keratin antibodies (AKA). Due to the strong correlation between PAD-mediated citrullination of synovial proteins and RA, understanding the causes and mechanisms of PAD catalyzed citrullination will likely provide insights into RA pathogenesis and also better define this clear target for therapeutic intervention.

\section{Multiple sclerosis (MS)}

PAD2-catalyzed citrullination of myelin basic protein (MBP) is thought to play an important role in demyelination of central nervous system (CNS) neurons in MS patients [40]. Under physiological conditions, MBP interacts with negatively charged phospholipids to stabilize the multilayered myelin. However, deregulation of PAD2 activity in the brain leads to increased MBP citrullination and the resulting loss of positive charge disrupts MBP-phospholipid interactions and increases myelin sheath instability [41-43]. MBP hypercitrullination also induces a more open MBP configuration, leading to cathepsin D-mediated enzymatic degradation and increased T-cell sensitivity [44, 45]. Interestingly, other substrates may also be targeted for citrullination in MS. For example, TNF- $\alpha$ has been found to promote nuclear translocation of PAD4 in brain tissue followed by PAD4-mediated histone $\mathrm{H} 3$ citrullination. This observation suggests that dysregulation of PAD4-mediated gene regulation may also play a role in the progression of MS [46].

\section{Alzheimer's disease $(A D)$}

Abnormal accumulation of citrullinated proteins such as vimentin and GFAP (glial fibrillary acidic protein) are found in the hippocampus of AD brains and these modified proteins show increased immunoreactivity compared to proteins from normal brain. Studies have also shown that citrullination of cerebral proteins by PAD2 occurs in regions undergoing neurodegeneration, suggesting that citrullination may promote the progression of neurodegenerative disease $[47,48]$. 


\section{PADs and Inflammation}

Given the strong associations with RA, MS, and Alzheimer's disease, PADs have previously been primarily linked to inflammatory autoimmune diseases. However, PAD-mediated citrullination is also elevated in a range of inflammatory states which lack a strong autoimmune component including myositis, tobacco induced pulmonary disease, and tonsillitis [15]. Additionally, a very recent study found that PAD expression and activity were elevated in a mouse biopsy wound healing assay that models physiological inflammatory conditions [49]. Lastly, we have found that PAD4-mediated histone hypercitrullination plays a critical role in chromatin release during neutrophil extracellular trap (NET) formation in granulocytes [34]. NET formation occurs in response to inflammatory mediators and does not necessarily involve an autoimmune component. These observations suggest that PAD-mediated citrullination may play a fundamental role in the inflammatory process and, thus, is likely to be involved in a wider range of physiological and pathological processes than previously envisioned. While the link between PADs and inflammation has recently developed in non-reproductive tissues, such an association has yet to be investigated in reproductive tissues.

\section{A Role for PADs in Female Reproduction}

As discussed below, some of the earliest PAD literature documented PAD expression and activity in female reproductive tissues. However, in more recent years, other than our work documenting the role of PAD6 in female fertility and on the role of PADs in gene regulation in mammary epithelial cells, the link between PADs and reproduction has not been further developed. To highlight the potential importance of PADs in female reproductive tissue, we examined PAD tissue distribution patterns in datasets utilizing modern transcriptomic techniques. For example, Massively Parallel Signature Sequencing (which can determine absolute gene expression profiles) was utilized to evaluate mRNA expression patterns across a broad range of mouse tissues [50]. Analysis of this dataset found that expression levels of PADs 1, 2, 4, and 6 across more than 50 tissues was highest in female reproductive tissues such as the uterus, cervix, and vagina. Analysis of data from cDNA microarrays by Hewitt et al. further strengthens the association of PADs with reproduction by showing that estrogen induces the expression of PAD1, 2, and 4 in uterine tissue [51]. In this study, ovariectomized mice were treated with estrogen and uterine samples harvested at $0.5,2,6,12$, and 24 hours post treatment. The microarray data shows that estrogen treatment increases uterine PAD1 and PAD2 expression by $>3$ fold within 2 hours of treatment and this level of increase is achieved for PAD4 after 12 hours. Expression of PAD mRNA levels was also compared in the uteri of ovariectomized wild type, $\alpha$ ERKO (ER $\alpha$ knockout mice), and $\mathrm{KI} / \mathrm{KO}$ (ER binding mutant) mice after estrogen treatment [52]. Both $\alpha$ ERKO and KI/KO mice uteri show decreased levels of PAD1, 2 and 4 expression compared to wild type uteri at 2 and $24 \mathrm{~h}$ indicating that ER $\alpha$ appears to be involved in the expression of these PAD family members. Strengthening the link between ER and PAD expression, PAD1 appears to contain 2 EREs (Estrogen

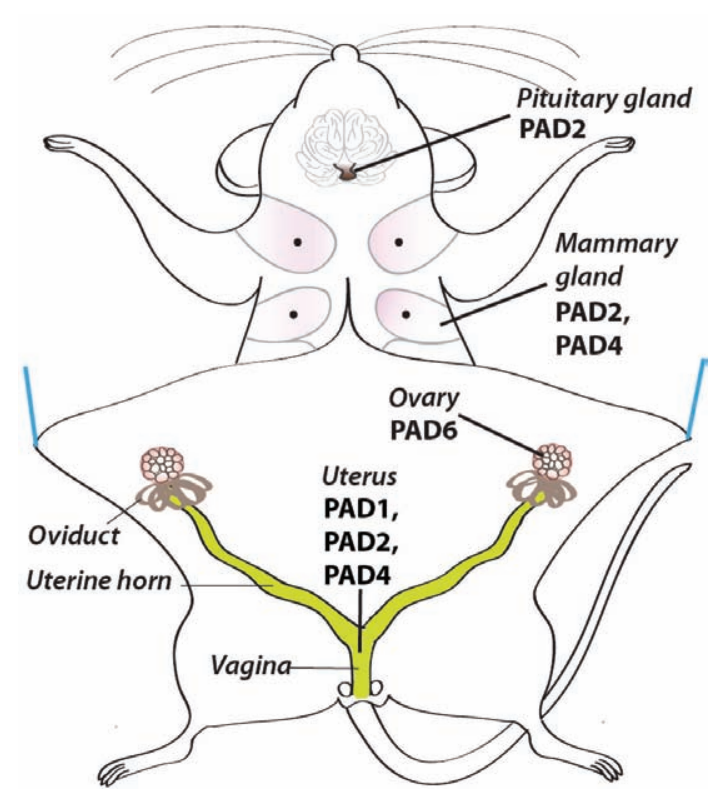

Fig. 3. PAD localization in the reproductive tissues: pituitary gland, mammary gland, ovary, and uterus.

Response Element) while PAD4 appears to have one canonical ERE [53]. PAD3, which also appears to contain a canonical ERE, is not expressed in uterine tissue while PAD2, which does not appear to contain an ERE, is expressed in the uterus. PAD2's estrogen responsiveness, however, may potentially be explained by ER $\alpha$ interactions with the transcription factor Spl, which binds the PAD2 promoter at multiple sites [54].

This newer transcriptome data supports a strong association between PADs and female reproduction and reinforces the existing literature characterizing the localization and distribution of the PAD gene family in female reproductive organs. A summary of PAD expression in the reproductive tract is shown in Fig. 3. Before discussing the older literature, it is important to first note here that the initial studies on PAD biology focused on a single enzyme termed "peptidylarginine deiminase" or alternatively called "skeletal muscle peptidylarginine deiminase" before the discovery of the different isoforms of the family. With availability of full genome sequences, it is now clear that the first cDNA clones isolated from rat skeletal muscle and mouse uterus are in fact PAD2 $[55,56]$. However, the use of enzymatic activity assays on whole tissue extracts and potentially cross-reactive antibodies makes it difficult to pinpoint exactly which isoform is being discussed in some of these early studies.

\section{Pituitary}

One of the first tissues studied in PAD biology was the pituitary gland. Based on the cDNA sequence, tissue isolation, and antibodies, the isoform detected in the pituitary appears likely to be PAD2 [56, 57]. Using pituitary lysates, investigators noticed a strong sexual dimorphism with a high level of PAD activity in the female rat pituitary, while little enzymatic activity was seen 
in the pituitary gland from males. Negligible PAD enzymatic activity was detected in 3-week old female pituitary, but by about 4 months of age, activity increased substantially, suggesting that sexual maturation contributes to PAD expression [58]. In rats, serum estrogen (17 $\beta$-estradiol) concentration varies during the estrous cycle, gradually increasing during metestrus, peaking at proestrus, followed by a sharp decrease during estrus [59]. Estrous cycle-staged rats showed a two-fold higher PAD activity level in pituitary lysates during proestrus and estrus than during metestrus and diestrus stages. Thus, the rise in 17 $\beta$-estradiol serum levels just prior to increased PAD activity levels suggests that the fluctuations of the hormone during the estrous cycle plays an important role in PAD expression in the pituitary [58].

Further studies strengthened the role of estrogen in PAD expression. First, Senshu et al. showed that ovariectomy of rats causes a severe drop in pituitary PAD activity; however, this activity could be restored by repeated injections of $17 \beta$-estradiol $[58,60]$. Interestingly, they also found that, in the pituitary, PAD mRNA levels did not directly correlate with enzymatic activity, leading the authors to speculate that PAD mRNA might be regulated at the translational and stability levels [60]. Second, investigators found that $17 \beta$-estradiol causes a dose-dependent increase in PAD biosynthesis and activity, reaching levels four- to fivefold higher than that of controls in the somato-lactotroph rat pituitary-derived $\mathrm{MtT} / \mathrm{S}$ cells line [61]. At the same time, the authors found that other steroid hormones such as testosterone, progesterone, and corticosterone did not affect PAD activity in MtT/S cells.

Interestingly, insulin also increases PAD biosynthesis and activity in MtT/S cells in a dose-dependent manner [62]. The increase in insulin-induced PAD levels was found to occur prior to prolactin biosynthesis suggesting that elevated PAD levels may be important for regulating prolactin expression in lactotrophs; one of the five hormone-secreting cell types in the anterior pituitary gland. Immunohistochemical and immunofluoresecent studies were carried out in the rat anterior pituitary gland and localized PAD expression to prolactin-secreting lactotrophs [63]. A substantial and steady rise in PAD activity is seen from day 7 of pregnancy through day 14 in the rat pituitary. Given that an increase in $17 \beta$-estradiol levels normally precedes lactotroph proliferation and prolactin biosynthesis and that, in pregnant rats, estrogen levels remain low during early to mid-pregnancy, this observation suggests that other factors may be regulating PAD expression in the pituitary during pregnancy.

\section{Mammary gland}

The role of PAD expression in the mammary gland is a relatively young field of investigation and, to date, it appears that PAD2 and 4 are the main isoforms expressed in this tissue. The majority of the work studying the role of PAD4 in the mammary gland has focused on epigenetic control of gene expression using human breast cancer cell lines. For example, in 2004 a report by Wang et al. documented how human PAD4 can convert methyl-arginine residues on histone $\mathrm{H} 3$ and 4 tails to the non-standard residue citrulline [28]. In the course of this study, the authors used the human mammary adenocarcinoma-derived MCF-7 cell line to show that endogenous PAD4 plays a role in regulating expression of the estrogen-responsive $\mathrm{pS} 2$ gene promoter. The PAD4 promoter was also characterized in MCF-7 cells and found to be estrogenresponsive due to ER $\alpha$ binding and ER $\alpha$ mediated increases in AP-1, $\mathrm{Sp1}$, and NF-Y transcription factor levels [64]. Further, work by Zhang et al. used a genome-wide approach to show that PAD4 is enriched at transcriptional start sites and is primarily associated with actively transcribed genes in MCF-7 cells. Mechanistically, PAD4 was found to activate transcription of $c$-fos via citrullination of the transcription factor, Elk-1, thus potentiating subsequent Elk1 phosphorylation and histone $\mathrm{H} 4$ acetylation at this target [29]. Interestingly, several of the DNA elements associated with PAD4 activity correspond to recognition sites for transcription factors with known roles in mammary gland function such as STAT1, 3, and 5.

Most work to date has focused on the molecular role of PAD4 in gene regulation in cancer cells, with little emphasis on normal reproductive function or mammary tissue expression patterns. In an effort to address this issue, in this report we examined PAD4 expression patterns over the course of the estrous cycle in the mouse mammary fat pad and found that PAD4 is expressed at low but detectable levels in epithelial cells during estrus (Fig. 4a). In estrogen supplemented ovariectomized mice, PAD4 expression levels appear to increase in the nuclei of mammary epithelial cells compared to the placebo control, indicating that estrogen appears to regulate PAD4 expression in vivo (Fig 4b). The observation that PAD4 is expressed in the mouse mammary epithelium and that its expression is regulated by estrogen is supported by microarray data from the Korach lab [51].

Regarding PAD2, we found that its expression in the canine mammary gland appears to initiate during estrus, with the mRNA and protein levels peaking during diestrus [19]. Similar to the dog, here we found that PAD2 is expressed in epithelial cell populations within the mouse mammary fat pad during all stages of the estrus cycle, with the highest PAD2 expression being observed at estrus (Fig. 5a). In estrogen treated ovariectomized mice, PAD2 levels in mammary fat pads increase versus placebo control, clearly indicating a role for estrogen in driving PAD2 expression in mammary epithelial cells (Fig. 5b). Interestingly, PAD2 expression in the canine mammary gland is also estrous cycle dependent but appears to be out of phase with PAD expression patterns in the rodent mammary gland. This difference may be due to unique estrous cycle stage lengths and hormone levels in the two species, especially given that in the canine cycle, the luteal phase can last up to 100 days. Our previous report found that a fraction of PAD2 localizes to the nucleus of luminal epithelial cells in the canine mammary gland and that a major target of PAD2 in these cells appears to be histone H3 [19]. These findings, coupled with more recent data from our lab, suggest that future investigations into the roles of PAD2 and PAD4 in gene regulation via histone modification in normal mammary tissue and breast cancer will likely be highly productive.

\section{Uterus}

As noted above, recent transcriptomics studies found that, of more than 50 tissues examined, the uterus expresses the highest levels of PADs 1, 2, and 4 in the mouse. Thus, it is somewhat surprising how little is currently known about the role of PADs in uterine biology. In an effort to gain more insight into the localization and 
A.
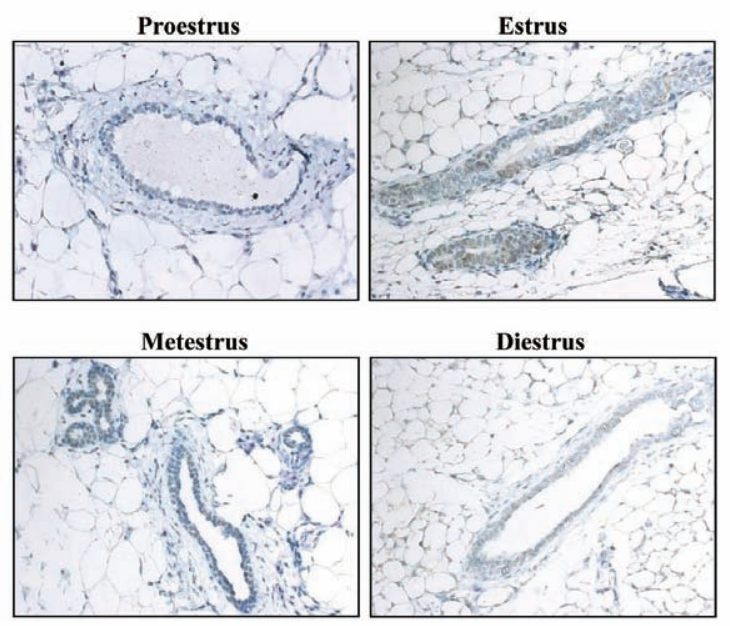

B.
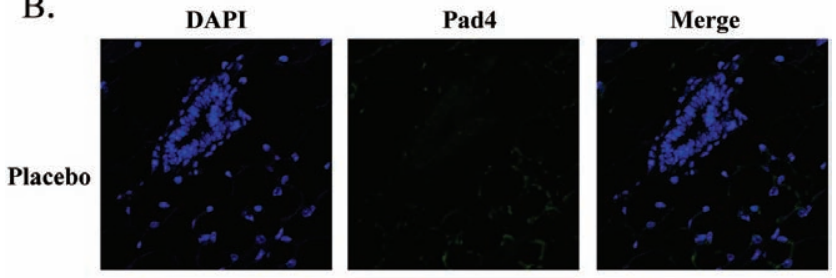

$\mathbf{E}_{2}$
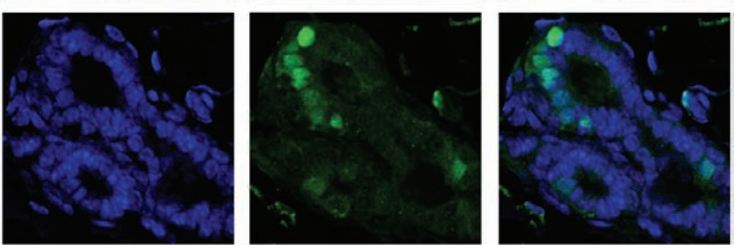

Fig. 4. PAD4 is expressed in epithelial cell populations in the mouse mammary fat pad. A: PAD4 expression is detected during the estrus phase of the mouse estrous cycle. Mice were estrous cycle staged by vaginal cytology and at each stage mammary fat pads were harvested and fixed in formalin. Tissue sections were probed with anti-PAD4 antibody or equal concentration of rabbit IgG as a control and counterstained with hematoxylin $(20 \times)$. B: PAD4 is expressed in the nuclei of mouse mammary epithelial cells following estrogen treatment. Mice were ovariectomized and implanted with either a slow release estrogen pellet or a placebo pellet as a control. After three weeks, mammary fat pads were collected and examined for PAD4 (green) expression using anti-PAD4 antibody or equal concentration of rabbit IgG as a control. Nuclei are stained with DAPI (blue) (40×).

regulation of PADs in the uterus, we probed uterine sections from estrous cycle staged mice using an anti-PAD4 antibody. We observed that PAD4 expression varies across the estrous cycle and localizes to luminal and glandular epithelial cells (Fig. 6a). To determine if PAD4 expression in the uterus is estrogen dependent, mice were ovariectomized and given either a placebo or slow release subcutaneous estrogen pellet for 3 weeks prior to immunohistochemical examination. Results showed that PAD4 expression is detected in the placebo control uterine tissue but that its expression increases following estrogen replacement (Fig 6b).

PAD2 is also expressed in uterine tissue and somewhat more characterized. Takahara et al. originally called the enzyme "pep-
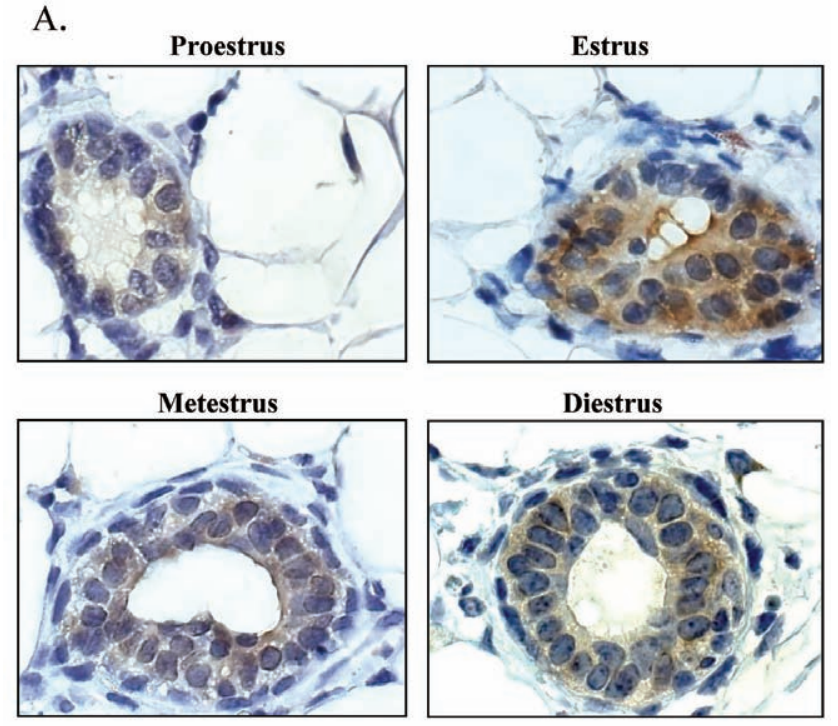

B.
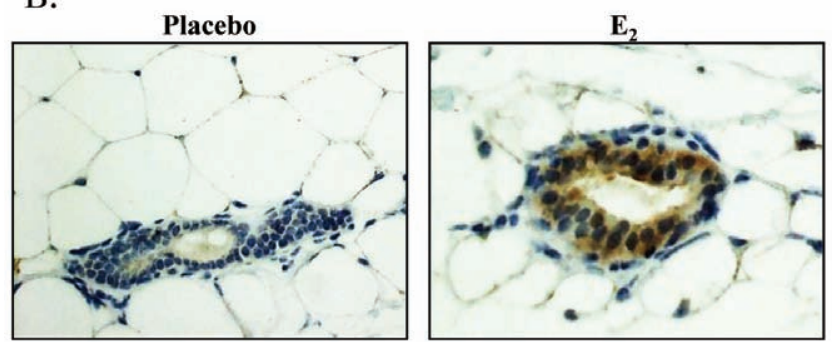

Fig. 5. PAD2 is expressed in epithelial cell populations in the mouse mammary fat pad. A: PAD2 is detected in all stages of the estrous cycle with highest expression during the estrus phase. Mice were estrous cycle staged by vaginal cytology and at each stage mammary fat pads were harvested and fixed in formalin. Tissue sections were probed with anti-PAD2 antibody or equal concentration of rabbit $\mathrm{IgG}$ as a control and counterstained with hematoxylin $(100 \times)$. B: PAD2 is expressed in mouse mammary epithelial cells following estrogen treatment. Mice were ovariectomized and implanted with either a slow release estrogen pellet or a placebo pellet as a control. After three weeks, mammary fat pads were collected and examined for PAD2 expression using anti-PAD2 antibody or equal concentration of rabbit $\operatorname{IgG}$ as a control and counterstained with hematoxylin $(40 \times)$.

tidylarginine deiminase"; however, they subsequently cloned a single isoform from uterine tissue and sequence analysis identified the protein as PAD2 [55, 65]. In their initial study, they showed that, similar to PADs 1 and 4, PAD2 expression localizes to luminal and glandular epithelia of the uterus and that its expression levels change over the course of the estrous cycle, with a peak in expression being found at proestrus. Similarly, PAD2 levels in the uterus were found to diminish after ovariectomy but were restored following 17ß-estradiol injection in a dose dependent manner [66]. Herein, we further validated the expression of PAD2 in uterine tissue using a commercially available anti-PAD2 antibody that 
A.

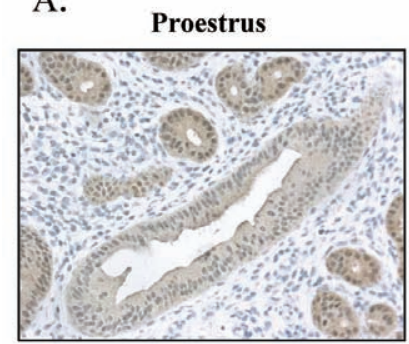

Metestrus

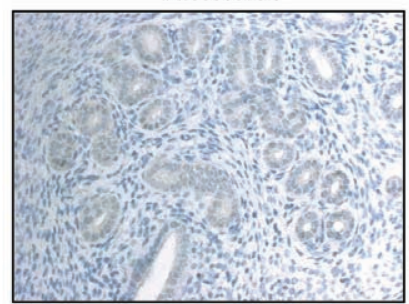

B.

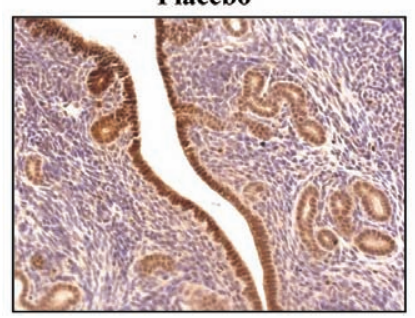

Estrus

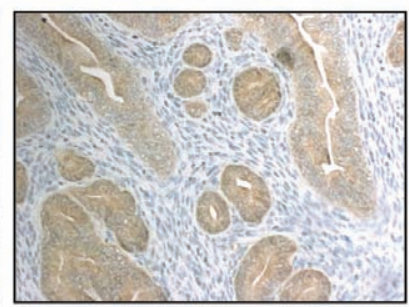

Diestrus
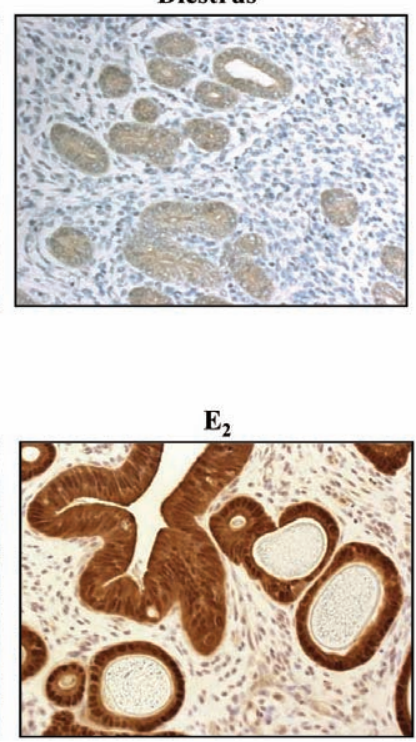

Fig. 6. PAD4 is expressed in luminal and glandular epithelial cell populations in the mouse uterus. A: PAD4 expression levels fluctuate across the mouse estrous cycle with highest expression detected during estrus. Mice were estrous cycle staged by vaginal cytology and at each stage uteri were harvested and fixed in formalin. Tissue sections were probed with anti-PAD4 antibody or equal concentration of rabbit IgG as a control and counterstained with hematoxylin (20×). B: PAD4 is expressed in mouse uteri epithelial cells following estrogen treatment. Mice were ovariectomized and implanted with either a slow release estrogen pellet or a placebo pellet as a control. After three weeks, uteri were collected and examined for PAD4 expression using anti-PAD4 antibody or equal concentration of rabbit IgG as a control and counterstained with hematoxylin (20×).

has previously been determined to be highly specific for PAD2 in that cross-reactivity to other PAD family members was not observed [19]. We also found that PAD2 is expressed in luminal and glandular epithelial cell populations within the mouse uterus in an estrous cycle dependent manner but with highest expression being observed during estrus (Fig. 7a). In ovariectomized mice treated with estrogen, PAD2 levels in uteri increase versus placebo control, clearly indicating the role of estrogen in driving PAD2 expression in uterine epithelial cell populations (Fig. 7b).

Regarding PAD1, older reports have found that mouse PAD1 expression in uterine tissue is also estrous cycle dependent with peak expression during proestrus and that PAD1 expression can be rescued after ovariectomy by exogenous estrogen treatment

A.
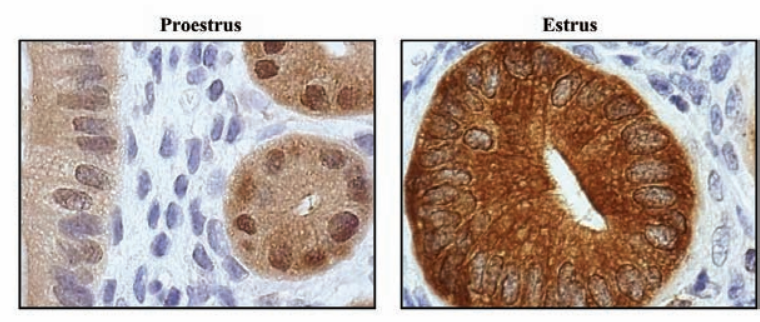

Metestrus
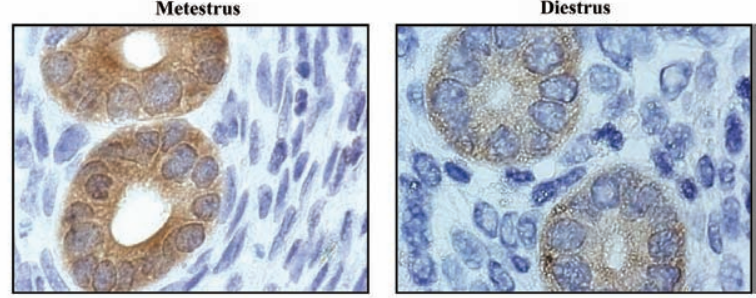

B.
DAPI

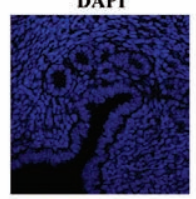

$\mathbf{E}_{2}$

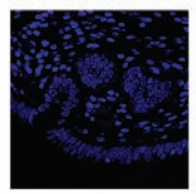

PAD2
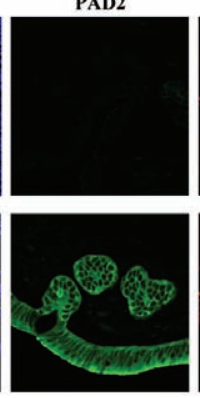
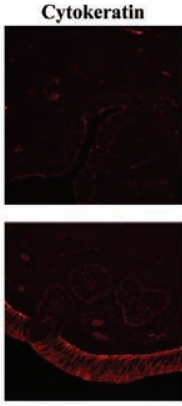
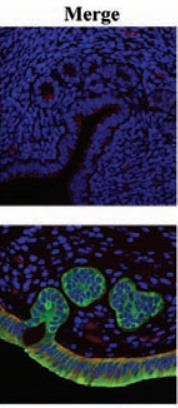

Fig. 7. PAD2 is expressed in luminal and glandular epithelial cell populations in the mouse uterus. A: PAD2 expression levels are highest during the estrus phase but present in all stages of the mouse estrous cycle. Mice were estrous cycle staged by vaginal cytology and at each stage uteri were harvested and fixed in formalin. Tissue sections were probed with anti-PAD2 antibody or equal concentration of rabbit IgG as a control and counterstained with hematoxylin $(100 \times)$. B: PAD2 is expressed in mouse uterine epithelial cells following estrogen treatment. Mice were ovariectomized and implanted with either a slow release estrogen pellet or a placebo pellet as a control. After three weeks, uteri were collected and examined for PAD2 (green) expression using anti-PAD2 antibody, cytokeratin (red) using an anti-cytokeratin antibody or equal concentration of rabbit IgG as a control. All nuclei are stained with DAPI (blue) $(40 \times)$.

$[13,67]$. Lastly, Takahara et al. showed that enzymatic activity in uterine tissue during estrus was 3-4 fold higher than that during diestrus, although this likely represents the combined activity of PADs 1, 2 and 4. Taken together, these findings support the prediction that multiple PAD family members are expressed in the uterus in an estrogen dependent manner and likely play a functional role in uterine biology.

\section{Ovary}

PAD6 appears to represent the major PAD family member in the ovary, with its expression being entirely limited to germ cells 
within this organ. PAD6 was first identified and cloned based on its absence of expression in somatic tissues and high protein expression levels in oocytes and pre-implantation embryos [14]. Through use of mutant mice, we have shown that PAD6 is essential for female fertility with the developmental arrest in PAD6-null mice occurring at the two-cell stage of development [68]. Additionally, we found that that PAD6 localizes to a poorly characterized cytoskeletal structure termed lattices located within oocytes and early embryos and that PAD6 is also essential for lattice formation [69]. Recently, we found that $\alpha$-tubulin associates with PAD6 at the lattices, and that PAD6 deletion causes altered microtubule formation and a dramatic suppression of stable microtubules. Further, we found that microtubule mediated organelle repositioning during oocyte maturation was defective in PAD6 null mice, suggesting that PAD6 and the lattices play a critical role regulating microtubule-based activities during oocyte maturation and, potentially, during early development [70]. While other PAD isoforms have not been previously described in normal ovaries, recent studies show PAD4 expression appears to be upregulated in ovarian tumors. Specifically, PAD4 is highly expressed in ovarian adenocarcinomas, but minimally expressed in benign ovarian cystadenomas, suggesting a role for PAD4 in the ovarian tumorigenesis [71].

\section{Could PADs Play a Role in Inflammation in the Female Reproductive Tract?}

As noted earlier, PADs are increasingly associated with inflammatory processes in non-reproductive tissues. Thus, it is interesting to speculate that PAD-mediated inflammatory activities may also play important roles in the female reproductive tract. For example, reproductive hormone-driven changes in the uterus can be viewed as an inflammatory process, as evidenced by the increased endometrial expression of inflammatory cytokines and chemokines and the accompanying infiltration of natural killer cells and other leucocytes into this tissue [72]. During the secretory phase of the estrous cycle, expression of the chemokines CXCL10 and CXCL11 by the human endometrium is high and appears to be regulated by both estradiol and progesterone [73]. Interestingly, CXCL10 and CXCL11 have been found to be citrullinated by PAD2, and this modification subsequently alters their chemoattracting and signaling capacity [74]. Thus, it is possible that elevated PAD levels in the endometrium during the secretory phase of the estrous cycle may function to citrullinate proteins such as CXCL10 and CXCL11 and thereby modulate the inflammatory response in the uterus. Another clear link to inflammatory pathways in female reproduction is the process of ovulation, which has long been described as an inflammatory reaction $[75,76]$. It is currently unclear if oocyte-derived PAD6 plays any role in the ovulation process, however, our finding that PAD6 appears to play a critical role in oocyte maturation, which precedes ovulation, makes this idea intriguing possibility.

\section{Conclusions}

Given the abundance of PADs 1-4 in female reproductive tissues, it seems possible that, in addition to PAD6, other PADs will likely be found to play important roles in female reproduction. In the coming years, the generation and analysis of mice with mutated versions of these PADs will likely directly test this hypothesis. Additionally, a range of new isoform-specific PAD inhibitors are also currently in development and the use of these inhibitors in mouse studies will also likely test whether citrullination is required for specific aspects of female reproduction.

\section{Acknowledgements}

This work was supported by:

1) NICHD grant RO1 38353 to SAC.

2) DOD Era of Hope Scholar Award (grant W871XWH-071-0372) to SAC.

The authors would like to thank Dr K Korach and S Hewitt at NIEHS for providing further insight into their microarray studies examining estrogen receptor-dependent genomic responses in mammary and uterine tissue of mice.

\section{Reference}

1. György B, Toth E, Tarcsa E, Falus A, Buzas EI. Citrullination: a posttranslational modification in health and disease. Int J Biochem Cell Biol 2006; 38: 1662-1677. [Medline] [CrossRef]

2. Méchin MC, Sebbag M, Arnaud J, Nachat R, Foulquier C, Adoue V, Coudane F, Duplan H, Schmitt AM, Chavanas S, Guerrin M, Serre G, Simon M. Update on peptidylarginine deiminases and deimination in skin physiology and severe human diseases. Int J Cosmet Sci 2007; 29: 147-168. [Medline] [CrossRef]

3. Vossenaar ER, Zendman AJ, van Venrooij WJ, Pruijn GJ. PAD, a growing family of citrullinating enzymes: genes, features and involvement in disease. Bioessays 2003; 25: 1106-1118. [Medline] [CrossRef]

4. Tarcsa E, Marekov LN, Mei G, Melino G, Lee SC, Steinert PM. Protein unfolding by peptidylarginine deiminase. Substrate specificity and structural relationships of the natural substrates trichohyalin and filaggrin. J Biol Chem 1996; 271: 30709 30716. [Medline] [CrossRef]

5. Chavanas S, Mechin MC, Takahara H, Kawada A, Nachat R, Serre G, Simon M. Comparative analysis of the mouse and human peptidylarginine deiminase gene clusters reveals highly conserved non-coding segments and a new human gene, PADI6. Gene 2004; 330: 19-27. [Medline] [CrossRef]

6. Senshu T, Kan S, Ogawa H, Manabe M, Asaga H. Preferential deimination of keratin $\mathrm{K} 1$ and filaggrin during the terminal differentiation of human epidermis. Biochem Biophys Res Commun 1996; 225: 712-719. [Medline] [CrossRef]

7. Nachat R, Mechin MC, Takahara H, Chavanas S, Charveron M, Serre G, Simon M. Peptidylarginine deiminase isoforms 1-3 are expressed in the epidermis and involved in the deimination of $\mathrm{K} 1$ and filaggrin. J Invest Dermatol 2005; 124: 384-393. [Medline] [CrossRef]

8. Rawlings AV, Harding CR. Moisturization and skin barrier function. Dermatol Ther 2004; 17(Suppl 1): 43-48. [Medline] [CrossRef]

9. Senshu T, Akiyama K, Ishigami A, Nomura K. Studies on specificity of peptidylarginine deiminase reactions using an immunochemical probe that recognizes an enzymatically deiminated partial sequence of mouse keratin K1. J Dermatol Sci 1999; 21 113-126. [Medline] [CrossRef]

10. Gan SQ, McBride OW, Idler WW, Markova N, Steinert PM. Organization, structure, and polymorphisms of the human profilaggrin gene. Biochemistry 1991; 30: 5814. [Medline]

11. Ishida-Yamamoto A, Senshu T, Eady RA, Takahashi H, Shimizu H, Akiyama M, Iizuka H. Sequential reorganization of cornified cell keratin filaments involving filaggrin-mediated compaction and keratin 1 deimination. J Invest Dermatol 2002; 118: 282-287. [Medline] [CrossRef]

12. Simon M, Haftek M, Sebbag M, Montezin M, Girbal-Neuhauser E, Schmitt D, Serre G. Evidence that filaggrin is a component of cornified cell envelopes in human plantar epidermis. Biochem J 1996; 317: 173-177. [Medline]

13. Terakawa $\mathbf{H}$, Takahara $\mathbf{H}$, Sugawara $\mathbf{K}$. Three types of mouse peptidylarginine deiminase: characterization and tissue distribution. J Biochem 1991; 110: 661-666. [Medline]

14. Wright PW, Bolling LC, Calvert ME, Sarmento OF, Berkeley EV, Shea MC, Hao 
Z, Jayes FC, Bush LA, Shetty J, Shore AN, Reddi PP, Tung KS, Samy E, Allietta MM, Sherman NE, Herr JC, Coonrod SA. ePAD, an oocyte and early embryoabundant peptidylarginine deiminase-like protein that localizes to egg cytoplasmic sheets. Dev Biol 2003; 256: 73-88. [Medline] [CrossRef]

15. Makrygiannakis D, af Klint E, Lundberg IE, Lofberg R, Ulfgren AK, Klareskog L, Catrina AI. Citrullination is an inflammation-dependent process. Ann Rheum Dis 2006; 65: 1219-1222. [Medline] [CrossRef]

16. Vossenaar ER, Radstake TR, van der Heijden A, van Mansum MA, Dieteren C, de Rooij DJ, Barrera P, Zendman AJ, van Venrooij WJ. Expression and activity of citrullinating peptidylarginine deiminase enzymes in monocytes and macrophages. Ann Rheum Dis 2004; 63: 373-381. [Medline] [CrossRef]

17. Lee HJ, Joo M, Abdolrasulnia R, Young DG, Choi I, Ware LB, Blackwell TS, Christman BW. Peptidylarginine deiminase 2 suppresses inhibitory kappa B kinase activity in lipopolysaccharide-stimulated RAW 264.7 macrophages. J Biol Chem 2010; 285: 39655-39662. [Medline] [CrossRef]

18. Proost P, Loos T, Mortier A, Schutyser E, Gouwy M, Noppen S, Dillen C, Ronsse I, Conings R, Struyf S, Opdenakker G, Maudgal PC, Van Damme J. Citrullination of CXCL8 by peptidylarginine deiminase alters receptor usage, prevents proteolysis, and dampens tissue inflammation. $J$ Exp Med 2008; 205: 2085-2097. [Medline] [CrossRef]

19. Cherrington BD, Morency E, Struble AM, Coonrod SA, Wakshlag JJ. Potential role for peptidylarginine deiminase 2 (PAD2) in citrullination of canine mammary epithelial cell histones. PLoS One 2010; 5: e11768. [Medline] [CrossRef]

20. Jang B, Shin HY, Choi JK. Nguyen du PT, Jeong BH, Ishigami A, Maruyama N, Carp RI, Kim YS, Choi EK. Subcellular localization of peptidylarginine deiminase 2 and citrullinated proteins in brains of scrapie-infected mice: nuclear localization of PAD2 and membrane fraction-enriched citrullinated proteins. J Neuropathol Exp Neurol 2011; 70: 116-124. [Medline] [CrossRef]

21. Kanno T, Kawada A, Yamanouchi J, Yosida-Noro C, Yoshiki A, Shiraiwa M, Kusakabe M, Manabe M, Tezuka T, Takahara H. Human peptidylarginine deiminase type III: molecular cloning and nucleotide sequence of the cDNA, properties of the recombinant enzyme, and immunohistochemical localization in human skin. J Invest Dermatol 2000; 115: 813-823. [Medline] [CrossRef]

22. Rogers G, Winter B, McLaughlan C, Powell B, Nesci T. Peptidylarginine deiminase of the hair follicle: characterization, localization, and function in keratinizing tissues. J Invest Dermatol 1997; 108: 700-707. [Medline] [CrossRef]

23. Guerrin M, Ishigami A, Mechin MC, Nachat R, Valmary S, Sebbag M, Simon M, Senshu T, Serre G. cDNA cloning, gene organization and expression analysis of human peptidylarginine deiminase type I. Biochem J 2003; 370: 167-174. [Medline] [CrossRef]

24. Taresa E, Marekov LN, Andreoli J, Idler WW, Candi E, Chung SI, Steinert PM. The fate of trichohyalin. Sequential post-translational modifications by peptidylarginine deiminase and transglutaminases. J Biol Chem 1997; 272: 27893-27901. [Medline] [CrossRef]

25. Chavanas S, Adoue V, Mechin MC, Ying S, Dong S, Duplan H, Charveron M, Takahara H, Serre G, Simon M. Long-range enhancer associated with chromatin looping allows AP-1 regulation of the peptidylarginine deiminase 3 gene in differentiated keratinocyte. PLoS One 2008; 3: e3408. [Medline] [CrossRef]

26. Asaga H, Nakashima K, Senshu T, Ishigami A, Yamada M. Immunocytochemical localization of peptidylarginine deiminase in human eosinophils and neutrophils. $J$ Leukoc Biol 2001; 70: 46-51. [Medline]

27. Nakashima K, Hagiwara T, Yamada M. Nuclear localization of peptidylarginine deiminase V and histone deimination in granulocytes. J Biol Chem 2002; 277: 49562 49568. [Medline] [CrossRef]

28. Wang Y, Wysocka J, Sayegh J, Lee YH, Perlin JR, Leonelli L, Sonbuchner LS, McDonald CH, Cook RG, Dou Y, Roeder RG, Clarke S, Stallcup MR, Allis CD, Coonrod SA. Human PAD4 regulates histone arginine methylation levels via demethylimination. Science 2004; 306: 279-283. [Medline] [CrossRef]

29. Zhang X, Gamble MJ, Stadler S, Cherrington BD, Causey CP, Thompson PR, Roberson MS, Kraus WL, Coonrod SA. Genome-wide analysis reveals PADI4 cooperates with Elk-1 to activate c-Fos expression in breast cancer cells. PLoS Genet 2011; 7: e1002112. [Medline] [CrossRef]

30. Lee YH, Coonrod SA, Kraus WL, Jelinek MA, Stallcup MR. Regulation of coactivator complex assembly and function by protein arginine methylation and demethylimination. Proc Natl Acad Sci USA 2005; 102: 3611-3616. [Medline] [CrossRef]

31. Li P, Yao H, Zhang Z, Li M, Luo Y, Thompson PR, Gilmour DS, Wang Y. Regulation of $\mathrm{p} 53$ target gene expression by peptidylarginine deiminase 4. Mol Cell Biol 2008; 28: 4745-4758. [Medline] [CrossRef]

32. Yao H, Li P, Venters BJ, Zheng S, Thompson PR, Pugh BF, Wang Y. Histone Arg modifications and p53 regulate the expression of OKL38, a mediator of apoptosis. $J$ Biol Chem 2008; 283: 20060-20068. [Medline] [CrossRef]

33. Wang Y, Li M, Stadler S, Correll S, Li P, Wang D, Hayama R, Leonelli L, Han H,
Grigoryev SA, Allis CD, Coonrod SA. Histone hypercitrullination mediates chromatin decondensation and neutrophil extracellular trap formation. J Cell Biol 2009; 184: 205-213. [Medline] [CrossRef]

34. Liu YL, Chiang YH, Liu GY, Hung HC. Functional role of dimerization of human peptidylarginine deiminase 4 (PAD4). PLoS One 2011; 6: e21314. [Medline] [CrossRef]

35. Chang X, Yamada R, Suzuki A, Sawada T, Yoshino S, Tokuhiro S, Yamamoto K. Localization of peptidylarginine deiminase 4 (PADI4) and citrullinated protein in synovial tissue of rheumatoid arthritis. Rheumatology (Oxford) 2005; 44: 40-50. [Medline] [CrossRef]

36. van Beers JJ, Raijmakers R, Alexander LE, Stammen-Vogelzangs J, Lokate AM, Heck AJ, Schasfoort RB, Pruijn GJ. Mapping of citrullinated fibrinogen B-cell epitopes in rheumatoid arthritis by imaging surface plasmon resonance. Arthritis Res Ther 2010; 12: R219. [Medline] [CrossRef]

37. Schellekens GA, de Jong BA, van den Hoogen FH, van de Putte LB, van Venrooij WJ. Citrulline is an essential constituent of antigenic determinants recognized by rheumatoid arthritis-specific autoantibodies. J Clin Invest 1998; 101: 273-281. [Medline] [CrossRef]

38. Girbal-Neuhauser E, Durieux JJ, Arnaud M, Dalbon P, Sebbag M, Vincent C, Simon M, Senshu T, Masson-Bessiere C, Jolivet-Reynaud C, Jolivet M, Serre G. The epitopes targeted by the rheumatoid arthritis-associated antifilaggrin autoantibodies are posttranslationally generated on various sites of (pro)filaggrin by deimination of arginine residues. J Immunol 1999; 162: 585-594. [Medline]

39. Masson-Bessière $\mathbf{C}$, Sebbag $\mathbf{M}$, Girbal-Neuhauser E, Nogueira $\mathbf{L}$, Vincent $\mathbf{C}$, Senshu T, Serre G. The major synovial targets of the rheumatoid arthritis-specific antifilaggrin autoantibodies are deiminated forms of the alpha- and beta-chains of fibrin. J Immunol 2001; 166: 4177-4184. [Medline]

40. Lamensa JW, Moscarello MA. Deimination of human myelin basic protein by a peptidylarginine deiminase from bovine brain. J Neurochem 1993; 61: 987-996. [Medline] [CrossRef]

41. Moscarello MA, Wood DD, Ackerley C, Boulias C. Myelin in multiple sclerosis is developmentally immature. J Clin Invest 1994; 94: 146-154. [Medline] [CrossRef]

42. Musse AA, Li Z, Ackerley CA, Bienzle D, Lei H, Poma R, Harauz G, Moscarello MA, Mastronardi FG. Peptidylarginine deiminase 2 (PAD2) overexpression in transgenic mice leads to myelin loss in the central nervous system. Dis Model Mech 2008; 1: 229-240. [Medline] [CrossRef]

43. Wood DD, Ackerley CA, Brand B, Zhang L, Raijmakers R, Mastronardi FG, Moscarello MA. Myelin localization of peptidylarginine deiminases 2 and 4: comparison of PAD2 and PAD4 activities. Lab Invest 2008; 88: 354-364. [Medline] [CrossRef]

44. Pritzker LB, Joshi S, Gowan JJ, Harauz G, Moscarello MA. Deimination of myelin basic protein. 1. Effect of deimination of arginyl residues of myelin basic protein on its structure and susceptibility to digestion by cathepsin D. Biochemistry 2000;39: 5374-5381. [Medline] [CrossRef]

45. Tranquill LR, Cao L, Ling NC, Kalbacher H, Martin RM, Whitaker JN. Enhanced $\mathrm{T}$ cell responsiveness to citrulline-containing myelin basic protein in multiple sclerosis patients. Mult Scler 2000; 6: 220-225. [Medline]

46. Mastronardi FG, Wood DD, Mei J, Raijmakers R, Tseveleki V, Dosch HM, Probert L, Casaccia-Bonnefil P, Moscarello MA. Increased citrullination of histone H3 in multiple sclerosis brain and animal models of demyelination: a role for tumor necrosis factor-induced peptidylarginine deiminase 4 translocation. J Neurosci 2006; 26: 11387-11396. [Medline] [CrossRef]

47. Asaga H, Akiyama K, Ohsawa T, Ishigami A. Increased and type II-specific expression of peptidylarginine deiminase in activated microglia but not hyperplastic astrocytes following kainic acid-evoked neurodegeneration in the rat brain. Neurosci Lett 2002; 326: 129-132. [Medline] [CrossRef]

48. Asaga $\mathbf{H}$, Ishigami A. Protein deimination in the rat brain after kainate administration: citrulline-containing proteins as a novel marker of neurodegeneration. Neurosci Lett 2001; 299: 5-8. [Medline] [CrossRef]

49. Coudane F, Mechin MC, Huchenq A, Henry J, Nachat R, Ishigami A, Adoue V, Sebbag M, Serre G, Simon M. Deimination and expression of peptidylarginine deiminases during cutaneous wound healing in mice. Eur J Dermatol 2011; 21: 376 384. [Medline]

50. Barrett T, Troup DB, Wilhite SE, Ledoux P, Rudnev D, Evangelista C, Kim IF, Soboleva A, Tomashevsky M, Marshall KA, Phillippy KH, Sherman PM, Muertter RN, Edgar R. NCBI GEO: archive for high-throughput functional genomic data. Nucleic Acids Res 2009; 37(Database issue): D885-D890. [Medline] [CrossRef]

51. Hewitt SC, Deroo BJ, Hansen K, Collins J, Grissom S, Afshari CA, Korach KS. Estrogen receptor-dependent genomic responses in the uterus mirror the biphasic physiological response to estrogen. Mol Endocrinol 2003; 17: 2070-2083. [Medline] [CrossRef]

52. O'Brien JE, Peterson TJ, Tong MH, Lee EJ, Pfaff LE, Hewitt SC, Korach KS, 
Weiss J, Jameson JL. Estrogen-induced proliferation of uterine epithelial cells is independent of estrogen receptor alpha binding to classical estrogen response elements. J Biol Chem 2006; 281: 26683-26692. [Medline] [CrossRef]

53. Bourdeau V, Deschenes J, Metivier R, Nagai Y, Nguyen D, Bretschneider N, Gannon F, White JH, Mader S. Genome-wide identification of high-affinity estrogen response elements in human and mouse. Mol Endocrinol 2004; 18: 1411-1427. [Medline] [CrossRef]

54. Dong S, Kojima T, Shiraiwa M, Mechin MC, Chavanas S, Serre G, Simon M, Kawada A, Takahara H. Regulation of the expression of peptidylarginine deiminase type II gene (PADI2) in human keratinocytes involves Sp1 and Sp3 transcription factors. J Invest Dermatol 2005; 124: 1026-1033. [Medline] [CrossRef]

55. Tsuchida M, Takahara H, Minami N, Arai T, Kobayashi Y, Tsujimoto H, Fukazawa C, Sugawara K. cDNA nucleotide sequence and primary structure of mouse uterine peptidylarginine deiminase. Detection of a 3'-untranslated nucleotide sequence common to the mRNA of transiently expressed genes and rapid turnover of this enzyme's mRNA in the estrous cycle. Eur J Biochem 1993; 215: 677-685. [Medline] [CrossRef]

56. Watanabe K, Senshu T. Isolation and characterization of cDNA clones encoding rat skeletal muscle peptidylarginine deiminase. J Biol Chem 1989; 264: 15255-15260. [Medline]

57. Watanabe K, Akiyama K, Hikichi K, Ohtsuka R, Okuyama A, Senshu T. Combined biochemical and immunochemical comparison of peptidylarginine deiminases present in various tissues. Biochim Biophys Acta 1988; 966: 375-383. [Medline] [CrossRef]

58. Senshu T, Akiyama K, Nagata S, Watanabe K, Hikichi K. Peptidylarginine deiminase in rat pituitary: sex difference, estrous cycle-related changes, and estrogen dependence. Endocrinology 1989; 124: 2666-2670. [Medline] [CrossRef]

59. Butcher RL, Collins WE, Fugo NW. Plasma concentration of LH, FSH, prolactin, progesterone and estradiol-17beta throughout the 4-day estrous cycle of the rat. Endocrinology 1974; 94: 1704-1708. [Medline] [CrossRef]

60. Watanabe K, Hikichi K, Nagata S, Senshu T. Estrous cycle dependent regulation of peptidylarginine deiminase transcripts in female rat pituitary. Biochem Biophys Res Commun 1990; 172: 28-34. [Medline] [CrossRef]

61. Nagata S, Senshu T. Peptidylarginine deiminase in rat and mouse hemopoietic cells. Experientia 1990; 46: 72-74. [Medline] [CrossRef]

62. Nagata S, Uehara T, Inoue K, Senshu T. Increased peptidylarginine deiminase expression during induction of prolactin biosynthesis in a growth-hormone-producing rat pituitary cell line, MtT/S. J Cell Physiol 1992; 150: 426-432. [Medline] [CrossRef]

63. Akiyama K, Inoue K, Senshu T. Immunocytochemical study of peptidylarginine deiminase: localization of its immunoreactivity in prolactin cells of female rat pituitaries. Endocrinology 1989; 125: 1121-1127. [Medline] [CrossRef]
64. Dong S, Zhang Z, Takahara H. Estrogen-enhanced peptidylarginine deiminase type IV gene (PADI4) expression in MCF-7 cells is mediated by estrogen receptoralpha-promoted transfactors activator protein-1, nuclear factor-Y, and Sp1. Mol Endocrinol 2007; 21: 1617-1629. [Medline] [CrossRef]

65. Takahara H, Tsuchida M, Kusubata M, Akutsu K, Tagami S, Sugawara K. Peptidylarginine deiminase of the mouse. Distribution, properties, and immunocytochemical localization. J Biol Chem 1989; 264: 13361-13368. [Medline]

66. Takahara H, Kusubata M, Tsuchida M, Kohsaka T, Tagami S, Sugawara K. Expression of peptidylarginine deiminase in the uterine epithelial cells of mouse is dependent on estrogen. J Biol Chem 1992; 267: 520-525. [Medline]

67. Rus'd AA, Ikejiri Y, Ono H, Yonekawa T, Shiraiwa M, Kawada A, Takahara H. Molecular cloning of cDNAs of mouse peptidylarginine deiminase type I, type III and type IV, and the expression pattern of type I in mouse. Eur J Biochem 1999; 259: 660-669. [Medline] [CrossRef]

68. Esposito G, Vitale AM, Leijten FP, Strik AM, Koonen-Reemst AM, Yurttas P, Robben TJ, Coonrod S, Gossen JA. Peptidylarginine deiminase (PAD) 6 is essential for oocyte cytoskeletal sheet formation and female fertility. Mol Cell Endocrinol 2007; 273: 25-31. [Medline] [CrossRef]

69. Yurttas P, Vitale AM, Fitzhenry RJ, Cohen-Gould L, Wu W, Gossen JA, Coonrod SA. Role for PADI6 and the cytoplasmic lattices in ribosomal storage in oocytes and translational control in the early mouse embryo. Development 2008; 135: 2627 2636. [Medline] [CrossRef]

70. Kan R, Yurttas P, Kim B, Jin M, Wo L, Lee B, Gosden R, Coonrod SA. Regulation of mouse oocyte microtubule and organelle dynamics by PADI6 and the cytoplasmic lattices. Dev Biol 2011; 350: 311-322. [Medline] [CrossRef]

71. Wang L, Chang X, Yuan G, Zhao Y, Wang P. Expression of peptidylarginine deiminase type 4 in ovarian tumors. Int J Biol Sci 2010; 6: 454-464. [Medline] [CrossRef]

72. King AE, Critchley HO. Oestrogen and progesterone regulation of inflammatory processes in the human endometrium. J Steroid Biochem Mol Biol 2010; 120: 116126. [Medline] [CrossRef]

73. Sentman CL, Meadows SK, Wira CR, Eriksson M. Recruitment of uterine NK cells: induction of CXC chemokine ligands 10 and 11 in human endometrium by estradiol and progesterone. J Immunol 2004; 173: 6760-6766. [Medline]

74. Loos T, Mortier A, Gouwy M, Ronsse I, Put W, Lenaerts JP, Van Damme J, Proost P. Citrullination of CXCL10 and CXCL11 by peptidylarginine deiminase: a naturally occurring posttranslational modification of chemokines and new dimension of immunoregulation. Blood 2008; 112: 2648-2656. [Medline] [CrossRef]

75. Espey LL. Ovulation as an inflammatory reaction--a hypothesis. Biol Reprod 1980; 22: 73-106. [Medline] [CrossRef]

76. Jabbour HN, Sales KJ, Catalano RD, Norman JE. Inflammatory pathways in female reproductive health and disease. Reproduction 2009; 138: 903-919. [Medline] [CrossRef] 